\title{
Custodiol HTK Versus Plegisol: in-Vitro Comparison With The Use of Immature (H9C2) and Mature (HCM) Cardiomyocytes Cultures
}

\author{
Rafał Nowicki ( $\nabla$ rafal.nowicki@umw.edu.pl) \\ Wroclaw Medical University \\ Mikołaj Berezowski \\ Wroclaw Medical University \\ Julita Kulbacka \\ Wroclaw Medical University \\ Katarzyna Bieżuńska-Kusiak \\ Wroclaw Medical University \\ Marek Jasiński \\ Wroclaw Medical University \\ Jolanta Saczko \\ Wroclaw Medical University
}

\section{Research Article}

Keywords: cardioplegia, cardiomyocyte cultures, oxidative stress

Posted Date: October 13th, 2021

DOI: https://doi.org/10.21203/rs.3.rs-765878/v1

License: () (1) This work is licensed under a Creative Commons Attribution 4.0 International License.

Read Full License

Version of Record: A version of this preprint was published at BMC Cardiovascular Disorders on March 17th, 2022. See the published version at https://doi.org/10.1186/s12872-022-02536-6. 


\section{Abstract}

Background: Although cardioplegia is used since the '70s of the last century, debate on cardioprotection during cardio-surgical procedures is still actual. The selection of a particular method depends mainly on the preferences and experience of a specific center or even surgeon. Crystalloid cardioplegia is an aqueous ion solution similar to intracellular (Custodiol HTK) or extracellular (Plegisol) fluid. Numerous publications compare different types of cardioplegic solutions, but only a few used cultured cells in laboratory conditions.

Methods: In this study, the authors compare two crystalloid solutions using an in-vitro model simulating cardioplegic arrest. The efficacy of myocardial protection during ischemia was investigated with susceptible indicators like the appearance of the deleterious effect of reactive oxygen species and oxidative stress markers. Incubated human cardiomyocytes and rat cardiomyoblasts $\mathrm{H} 9 \mathrm{C} 2$ in cardioplegia for $4 \mathrm{~h}$ were examined for expression of oxidative stress markers (MnSOD, iNOS, HSP27), cardioplegic solutions cytotoxicity, and peroxidation damage of the cell's lipids and proteins. All tests were performed after $0.5 \mathrm{~h}, 1 \mathrm{~h}, 2 \mathrm{~h}$, and $4 \mathrm{~h}$ in identical physical and biological conditions, which is difficult to achieve in clinical trials.

Results: The tests performed on matured cells of human cardiomyocytes showed the superiority of Custodiol HTK. Differences between solutions on immature cells H9C2 were not relevant. Both Plegisol and Custodiol HTK produced a similar expression of MnSOD and iNOS. There was no significant advantage of Custodiol over Plegisol in the cytotoxicity test. However, Custodiol induced a higher level of lipid peroxidation.

Conclusions: Considering proceeded examinations on cultured cardiomyocytes, Custodiol HTK appears to be safer than Plegisol.

\section{Background}

Cardiac surgery on the arrested heart with cardiopulmonary by-pass (CPB) has been a routine and safe method of treatment of numerous congenital and acquired heart diseases for dozens of years. However, the cessation of coronary circulation involves the risk of ischemia and post-ischemic (reperfusion) injury in the form of oxidative stress (OS) [1]. OS depends on the toxic effect of reactive oxygen species (ROS) during reperfusion time and their affinity to the cell structures, including lipids, proteins, and nucleic acids [2]. The oxidative reaction leads to cell malfunctions or even structural cell damage where the consequence is reversible or irreversible heart dysfunction (insufficiency).

In order to minimize the consequences of myocardial ischemia/reperfusion injury during cardio-surgical procedures, a number of protection methods have been introduced. The most important one is the administration of cardioplegia. The currently used cardioplegic solutions are divided into two groups, the first one, blood cardioplegia, is based on the patient's blood and the other one, the crystalloid cardioplegia, is an aqueous ion solution. Its formula is similar to the intracellular or extracellular fluid. 
Blood cardioplegia is obtained by mixing the patient's blood with crystalloid cardioplegia by a ratio of 4:1 or 8:1, another method is adding potassium ions directly to blood (e.g., Calafiore protocol) [ $\left.{ }^{3,4}\right]$. Cardioplegia is administered to the aortic root, directly to coronary ostia (antegrade), or coronary sinus (retrograde) at normothermia in hypothermia. The protective effect of cardioplegia consists of quick cardiac arrest in diastole by cell membrane depolarization and suppressing its mechanical and electric activity. The currently applied cardioplegic solutions are based on depolarizing abilities of potassium ions; however, researches are conducted on low-potassium cardioplegia using sodium and magnesium ions or other non-depolarizing substances. At present, there is no universal method of heart muscle protection [ $\left.{ }^{1}\right]$. The selection of a particular method depends mainly on the preferences and experience of a particular center or surgeon.

Although numerous publications compare different types of cardioplegic solutions, only a few of them used cultured cells in laboratory conditions. Our in vitro study aimed to evaluate the efficacy of two wellknown crystalloid cardioplegic solutions on cultured cardiomyocytes. The appearance of oxidative stress markers and damage of cultured cardiomyocytes after simulating the cardioplegic arrest were determined.

\section{Methods}

\section{Cells cultures}

Two cardiac cell lines were applied for in-vitro experiments. Rat cardiomyoblasts, immature cells - H9C2 (obtained from the Lab of Department of Medical Biochemistry, Wroclaw Medical University) which were grown in Dulbecco's Modified Eagle's Medium glucose (Lonza) with the addition of 10\% fetal bovine serum (FBS, Lonza), 2 mM Glutamine and 100x penicillin/streptomycin (Sigma). Primary human cardiac myocytes - HCM (PromoCell GmbH, Germany) were isolated from the ventricles of the adult heart and grown in Myocyte Growth Medium (C-22070, PromoCell GmbH, Germany) with the addition of Supplement Mix (C-39275, PromoCell GmbH, Germany). For experiments, the cells were removed by trypsinizing (0.25\% Trypsin-EDTA solution, Sigma), and washed with PBS. The cells were maintained in a humidified atmosphere at $37^{\circ} \mathrm{C}$ and $5 \% \mathrm{CO}_{2}$.

\section{Cardioplegia}

Custodiol HTK (Köhler Chemie GmbH, Germany) is intracellular ionic composed cardioplegia (low K囚) with the addition of three amino acids (histidine, tryptophan, ketoglutarate) and based on Bretschneider's solution introduced in $1975\left[^{5}\right]$. Custodiol HTK based on its buffering capacity, is often used as a singledose product.

Plegisol (Hospira Inc, USA) based on STH N² (St. Thomas' Hospital, London) extracellular solution (high $\mathrm{K} \otimes)$ as a multi-dose solution is used from the ${ }^{7} 70$ s of the last century $\left.{ }^{6}\right]$. Plegisol requires buffering with the $\mathrm{NaHCO} \bigotimes$ just before administration. The compositions of both solutions are shown in Table 1. 


\section{Simulation of the cardioplegic arrest and OS}

Cells were removed from medium and immersed in cooled $\left(4-6^{\circ} \mathrm{C}\right)$ both cardioplegic solutions incubated

for $0.5,1,2$, and 4 hours in a humidified atmosphere at $37^{\circ} \mathrm{C}$ and $5 \% \mathrm{CO}_{2}$. After that, the experiments were performed. The temperature of cardioplegic solutions and the specific period of incubation were similar to the intraoperative conditions. Thus, we simulated the ischemia, such as during the aorta crossclamping (arrest of the coronary perfusion). However, the typical reperfusion injury was not possible to obtain in our in-vitro model we provoked OS. The imbalance of prooxidant and antioxidant levels resulting from ischemia resulted in the overproduction of reactive oxygen species (ROS). However, the estimation of ROS concentration cannot be measured, the deleterious effect of ROS affected cellular lipids, proteins, and cardiomyocytes viability was examined in viability assay, the concentration of malondialdehyde (MDA) as an evidence of lipid peroxidation and determination of carbonyl groups caused by proteins damage. The presence of OS was also proven by the changes in antioxidative enzyme activity (iNOS, MnSOD) and chaperone activity protein (HSP27) which are regarded as OS markers.

\section{The viability assay and cytotoxicity}

The viable cardiomyocytes contain $\mathrm{NAD}(\mathrm{P}) \mathrm{H}$-dependent oxidoreductase (mitochondrial dehydrogenase) enzyme, which reduces MTT (tetrazolium salt (3-(4,5-dimethylthiazol-2-yl)-2,5-diphenyltetrazolium bromide) to insoluble formazan crystals. According to the protocol procedure, the cellular viability and the cytotoxic impact of cardioplegic solutions were determined by the MTT assay (Sigma, In VITRO Toxicology Assay). Cells were seeded into 96-well microculture plates (Nunc, Biokom) and allowed to attach for $24 \mathrm{~h}$. Then the incubation with Custodiol HTK or Plegisol for $0.5 \mathrm{~h}, 1 \mathrm{~h}, 2 \mathrm{~h}$, and $4 \mathrm{~h}$ was performed. The dissolved and colored formazan crystals were quantified spectrophotometrically by measuring the absorbance at $570 \mathrm{~nm}$ (Multiscan MS microplate reader, Theremo Fisher). The results were expressed as a percentage of the untreated control (percentage of control cells).

\section{Protocol for cells preparation for lipid peroxidation and carbonyl groups}

Cells were grown in $25 \mathrm{~cm}^{2}$ flasks (Nunc) to obtain full monolayer. Then they were incubated with Custodiol HTK or Plegisol for $0.5 \mathrm{~h}, 1 \mathrm{~h}, 2 \mathrm{~h}$, and $4 \mathrm{~h}$. After the treatment, cells with cardioplegia in-vitro were removed by trypsinizing and washed twice in PBS (IITD, PAN, Poland). Then cells suspensions (ca. 5 $\mathrm{x} 10^{6}$ ) were centrifuged $5 \mathrm{~min}$ at $1500 \mathrm{rpm}$ (Centrifuge MPW Med. Instruments MPW-341 with stable rotor).

\section{Lipid peroxidation}

Cell samples were suspended in $200 \mu \mathrm{L}$ of PBS. Then $200 \mu \mathrm{L}$ of $15 \% \mathrm{TCA}$ (trichloric acid; Roth) in $0.25 \mathrm{M}$ $\mathrm{HCl}$ and $200 \mu \mathrm{l}$ of $0.37 \%$ TBA in $0.25 \mathrm{M} \mathrm{HCl}$ were added. The control sample contained $200 \mu \mathrm{L}$ of deionized water instead of the cell suspension. Then the samples were incubated for 20 min at $90^{\circ} \mathrm{C}$ (Termoblock TB-941 U). After incubation, the samples were centrifuged for $5 \mathrm{~min}$ at $5000 \mathrm{rpm}$. MDA, the final product of fatty acid peroxidation, reacts with TBA to form a colored complex. The level of TBARS 
was measured based on the absorbance at the wavelength of $535 \mathrm{~nm}$. The concentration of malondialdehyde was quantified spectrophotometrically based on a set of MDA standards of known concentration. All measurements were performed on UV/Vis spectrophotometer (JASCO V-530, MEDSON).

\section{Proteins' damage - carbonyl groups}

Oxidative damage to proteins was investigated by determining carbonyl groups based on the reaction with dinitrophenylhydrazine (DNPH) (Sigma). Briefly, proteins were precipitated by the addition of $20 \%$ trichloroacetic acid (Sigma) and dissolved in $10 \mathrm{mM} \mathrm{DNPH}$, and the absorbance was read at $570 \mathrm{~nm}$. The results were calculated using an extinction coefficient of $\varepsilon=21.01 \mathrm{mmol}^{-1} / \mathrm{cm}^{-1}$ for aliphatic hydrazone. Experiments were repeated three times.

\section{Immunocytochemistry (MnSOD, iNOS, HSP27)}

Manganese superoxide dismutase (MnSOD) is a typical antioxidative enzyme located in mitochondria. It plays a crucial role in ROS scavenging and protecting mitochondria from oxidative damage. Inducible nitric oxide synthase (iNOS) catalyzes nitric oxide production, which prevents ROS formation and activates the synthesis of glutathione - another antioxidative factor. Heat shock protein 27 (HSP27) is regarded as a protein chaperone, antioxidant, and inhibits apoptosis. Immunocytochemistry was performed using the ABC method. Briefly, cultures were fixed and dehydrated using $4 \%$ paraformaldehyde and an ethanol gradient respectively. Samples were then permeabilized and blocked by incubation with $0.1 \%$ Triton X-100 (Sigma) in PBS. The expression of proteins was visualized with the mouse monoclonal antibody (1:100, Santa Cruz). For conventional bright-field microscopy (peroxidase-ABC labeling), the samples were incubated with the diaminobenzidine $-\mathrm{H}_{2} \mathrm{O}_{2}$ mixture (DAKO) to visualize the peroxidase label, counterstained with hematoxylin (Alchem, Poland) for $30 \mathrm{sec}$. Samples were examined on a simple Olympus microscope (BX41, Japan). Stained cell numbers were determined by counting 100 cells in 3 randomly selected fields. Two independent investigators performed the counting. The result was judged to be positive if staining was observed in more than $5 \%$ of cells. The intensity of immunocytochemical staining was evaluated as $(-)$ negative (no reaction), $(+)$ weak, $(++)$ moderate, and $(+++)$ strong. All experiments were repeated three times.

\section{Statistical analysis}

The normality of the continuous variables was checked by the Shapiro-Wilk test. The significance of the difference between mean values of different groups of cells (MTT test, lipid peroxidation, carbonyl groups concentration, MnSOD, iNOS and HSP27 expression) compared with the control group untreated cells) was assessed by Student's t-test with value of $p \leq 0.05$ taken as statistically significant. Statistical analysis was performed using STATISTICA 10 software.

\section{Results}




\section{Cell viability}

Both solutions were relatively safe and did not cause a decrease of cytotoxicity index under $50 \%$ up to the second hour of incubation time (Figure 1). A significant decrease was observed after four hours of incubation for both cardioplegic solutions. The viability of HCM cells maintained above $60 \%$ in every experiment for both of the cardioplegic solutions. The cytotoxicity of fluids grew with the time of incubation (Figure 1B).

\section{Lipid peroxidation}

In comparison to the control cells, only Custodiol HTK induced a slight increase of lipid peroxidation from $1 \mathrm{~h}$ to $2 \mathrm{~h}$ of incubation (Figure 2). After $4 \mathrm{~h}$ the MDA concentration dropped under control level. Plegisol did not provoke lipid peroxidation in $\mathrm{H} 9 \mathrm{C} 2$ cells during every applied incubation time. Custodiol HTK did not provoke lipids peroxidation in HCM cells. The MDA concentration was below the control level in samples after $1 \mathrm{~h}, 2 \mathrm{~h}$, and $4 \mathrm{~h}$ of incubation with both cardioplegic fluids. Only after $0.5 \mathrm{~h}$ of incubation with Plegisol, a slightly increased level of lipid peroxidation was observed $(p=0.000041)$, however MDA level was comparable to the control level.

\section{Proteins' damage (carbonyl groups concentration)}

Both cardioplegic solutions generated a statistically significant increase in carbonyl groups in $\mathrm{H} 9 \mathrm{C} 2$ cells (Figure 3). A significant increase of carbonyl group level was observed after $0.5 \mathrm{~h}$ and $2 \mathrm{~h}$ of incubation with Plegisol solution and after $1 \mathrm{~h}$ and $4 \mathrm{~h}$ with Custodiol HTK. Moreover, the raised level of carbonyl group concentration was independent on the time of incubation. The highest protein damage in $\mathrm{H} 9 \mathrm{C} 2$ cells was after $4 \mathrm{~h}$ of incubation with Custodiol HTK. The concentration of carbonyl groups in HCM cells showed a slight fluctuation comparing control cells. After $2 \mathrm{~h}$ of incubation with Custodiol HTK, the lowest concentration of carbonyl groups was observed.

\section{The evaluation of MnSOD}

The immunocytochemical analysis of MnSOD in cardiac cells is presented in Table 2A and Figure 4 for rat $\mathrm{H} 9 \mathrm{C} 2$ cells after $0.5 \mathrm{~h}$ and $4 \mathrm{~h}$ incubation with Custodiol HTK Plegisol, while results for HCM cells are shown in Figure 5 and Table 2B. After $0.5 \mathrm{~h}$ of incubation, MnSOD was detectable in $70 \%$ of incubated cells. The intensity of the reaction and the percentage of stained cells were similar in both examined cardioplegic solutions. A non-significant increase was observed after $1 \mathrm{~h}$ of incubation with Custodiol HTK (95\%) in comparison to incubation with Plegisol (70\%). MnSOD expression in HCM cells was significantly higher than in control cells. Any correlation between incubation time, the number of stained cells, reaction intensity, and the type of cardioplegia was not observed. A slightly stronger reaction was noticed in cells suspended in Plegisol after $0.5 \mathrm{~h}$ and $1 \mathrm{~h}$ compared to cells incubated with Custodiol HTK.

\section{The evaluation of iNOS}


The immunocytochemical evaluation of iNOS in cardiac cells is presented in Figure 6 for rat $\mathrm{H} 9 \mathrm{C} 2$ after $0.5 \mathrm{~h}, 1 \mathrm{~h}$ and $4 \mathrm{~h}$ of incubation with Plegisol and all the results for $\mathrm{H} 9 \mathrm{C} 2$ in Table $3 \mathrm{~A}$. In HCM cells, the effects of immunocytochemical study are shown in Figure 7 after $0.5 \mathrm{~h}$ and $2 \mathrm{~h}$ of incubation with Custodiol HTK or Plegisol and in Table 3B. The slight increase of iNOS expression was observed after $0.5 \mathrm{~h}, 1 \mathrm{~h}$, and $2 \mathrm{~h}$ of incubation in $\mathrm{H} 9 \mathrm{C} 2$ cells for both Custodiol and Plegisol solutions. At $4 \mathrm{~h}$ iNOS expression increased up to $20 \%$ (Custodiol HTK) and 25\% (Plegisol) of H9C2 cells. Custodiol HTK activated significantly higher iNOS expression in HCM cells than Plegisol and control cells. Seventy percent of cardiomyocytes incubated with Custodiol HTK has been stained already after $0.5 \mathrm{~h}$. The expression increased up to $95 \%$ after $2 \mathrm{~h}$ with strong reaction intensity (+++). iNOS expression suspended in Plegisol increased statistically considerably to $85 \%$ only after $2 \mathrm{~h}$ of incubation and dropped to $25 \%$ stained cells after $4 \mathrm{~h}$.

\section{The evaluation of HSP27}

The results from the immunocytochemically stained reaction are presented in Figure 8 for rat $\mathrm{H} 9 \mathrm{C} 2$ after $0.5 \mathrm{~h}, 1 \mathrm{~h}$ and $4 \mathrm{~h}$ incubation with Custodiol HTK or Plegisol and in Table 4A. For HCM cells the obtained results are shown in Figure 9 after $0.5 \mathrm{~h}, 1 \mathrm{~h}$ and $2 \mathrm{~h}$ of incubation with Plegisol and in Table 4B. Up to the first hour of incubation, the percentage of the stained cells was similar in both groups and significantly lower than control cells. After $2 \mathrm{~h}$ of incubation, Plegisol induced HSP27 expression more intensively than Custodiol HTK. After 4h incubation with Plegisol, 70\% of H9C2 were stained. Both cardioplegic solutions induced a decrease of HSP27 protein in HCM cells. Custodiol HTK has not activated the increasing expression of HSP27 in HCM cells. The HCM cells incubated with Plegisol demonstrated rising expression of HSP27 after $1 \mathrm{~h}$ and $2 \mathrm{~h}$ of incubation. After $4 \mathrm{~h}$ the reaction was not observed.

\section{Discussion}

The selection of an optimal strategy of heart protection is of utmost importance in modern cardiac surgery. According to the known comparative researches, there is no universal method of heart protection. The most popular one with depolarizing cardioplegic solutions allows to perform complicated surgical procedures, but it also has some significant limitations. Prolonging the ischemia period upsets cardiomyocytes' natural mechanisms against ischemia/reperfusion injury even if the protection protocol fully complies. The cardiac cells affected by the pathological process are even more sensitive to the deleterious effect of ischemia, leading to unsatisfactory operative results of patients during acute myocardial infarct, with impaired systolic function $\left[^{7}\right]$ or pulmonary hypertension $\left[{ }^{8}\right]$. Although crystalloid cardioplegia was introduced in the 70' of the last century is still an essential element in the whole cardiac operative protection strategy. There are a few well-known crystalloid solutions that use membrane depolarizing abilities of potassium ions. However, different ion concentrations and other added substances did not significantly influence the protective abilities of crystalloid cardioplegia, and the superiority of a specific solution has not been proven yet. 
Numerous researchers compared blood and crystalloid cardioplegia $[9,10,11,12,13,14-16]$, but only very few had compared different kinds of crystalloid solutions with unambiguous results. Brüll et al. showed better protective abilities of Bretschneider solution in comparison to St. Thomas-2 [ $\left.{ }^{17}\right]$. On the other hand, T. Demmy et al. in the multicenter clinical trial indicated more structural protein release (cTn-I) and adverse events in the CABG-patients protected with Custodiol HTK ${ }^{18}{ }^{18}$. Nevertheless, Cannata et al. did not find a correlation between the results of heart transplantation and the type of crystalloid cardioplegia $\left[{ }^{19}\right]$.

According to the results of the clinical trials, it remains unclear if the quality of cardioprotection is associated more with the type of cardioplegia or other factors like protocol and cardioplegia delivery, patient morbidity and status of coronary vessels, a protocol of anesthesia, type of surgical procedure and finally the surgeon experience $\left[^{[1}\right]$.

The present study considered cultured cells to be a helpful model allowing for standardized research protocol and objective cardioplegia assessment. Isolated cardiomyocytes are commonly applied as an explorative model in studies on ischemia and heart protection. Despite some disadvantages, Oldenburg et al. regarded cultured cardiomyocytes as a comfortable and economical example of an explorative research model. They indicated the possibility of performing reproducible experiments with a low dose of pharmacological agents under investigation. $\left[{ }^{20}\right]$ The other group of Wei et al. applied $\mathrm{H} 9 \mathrm{C} 2$ cells to examine the protective properties of NAC ( $\mathrm{N}$-acetylo-L-cystein) from ROS $\left[{ }^{21}\right]$. Dong et al. exposed H9C2 cells to chemical ischemia and demonstrated the protective effect of $H \otimes S$ by inhibition of protein kinase ERK1/2 [ $\left.{ }^{22}\right]$. Although cultured cardiomyocytes were not too often involved to compare cardioplegic solutions, Camilleri et al. were one of the first who confirmed the usefulness of cardiomyocytes to investigate crystalloid cardioplegia [ $\left.{ }^{23}\right]$. They proved lower toxicity of St. Thomas-2 as compared to classic Bretschneider solution on neonatal rat cardiomyoblasts which had been exposed to the chemical hypoxia.

Our study provoked ischemia by moving cells from the culture medium and plunged into cold cardioplegic solutions followed by incubation for $4 \mathrm{~h}$ simulating the intraoperative conditions. The presence of oxidative stress was proven by the increased level of oxidative stress markers. The chemical hypoxia was avoided to minimize its impact on the incubated cell.

The cytotoxicity index in MTT test on HCM did not decrease significantly within 4 hours of incubation, confirming no influence of both investigated cardioplegia solutions on the activity of mitochondrial dehydrogenase of HCM. However, the cytotoxicity index dropped below 50\% after 4 h of $\mathrm{H} 9 \mathrm{C} 2$ incubation with Plegisol. The highest dehydrogenase level was induced after incubation of HCM with Custodiol HTK at $2 \mathrm{~h}$ of incubation, statistically different from Plegisol. The predominance of Plegisol, but not statistically different, was observed after $0.5 \mathrm{~h}$ of $\mathrm{H} 9 \mathrm{C} 2$ incubation. On this basis, we may assume that Custodiol is less cytotoxic in comparison to Plegisol. Others have also applied cytotoxicity index in order to assess cytoprotection. Gomez et al. assessed the viability of isolated adult cardiomyocytes underwent stress factors analysis in the MTT testing, and revealed a direct cytoprotective effect of adenosine and 
hyperkalemic-cardioplegia $\left[{ }^{24}\right]$. Similarly, Drescher et al. used a cytotoxicity test to prove the cardioprotective property of hypothermia on $\mathrm{H} 9 \mathrm{C} 2$ cells incubated in a mixture of cardioplegia and culture medium [25].

One of the best-known oxidative stress markers is MnSOD. Previously, we examined the expression of MnSOD in the right atrium appendage of the cardioplegicaly arrested heart during coronary revascularization $\left.{ }^{26}\right]$. As we observed, the MnSOD expression increased in sections of the right atrium appendage by the rise of stain intensity and the percentage of cells with positive stain. Shlafer et al. showed better protective abilities of crystalloid cardioplegia after antioxidative enzyme supplementation (SOD, CAT) on isolated rabbit hearts $\left[{ }^{27}\right]$. Lee et al. proved the preventive role of Propofol in hypoxia/reoxygenation - induced apoptotic $\mathrm{H} 9 \mathrm{C} 2$ cells [ ${ }^{28}$ ]. In our research significant increase in MnSOD expression was observed, but no specific correlations between the intensity of reaction, the percentage of stained cells, and incubation time were found.

On the other hand, essential differences were observed in the expression of iNOS in HCM. There was an observed higher intensity of the immunocytochemical reaction against iNOS in HCM cells than neonatal $\mathrm{H} 9 \mathrm{C} 2$ cells. $\mathrm{HCM}$ are mature cells derived from the adult; thus, the mechanisms of antioxidative response are better developed. The role of iNOS signaling in myocardial cells is very complicated and highly confusing [29]. Inducible nitric oxide synthase activates after the external stimuli upon the presence of stress. The strong iNOS production may confirm myocardial protection $\left[{ }^{30}\right]$. Neonatal cells have these mechanisms weakly developed; thus, this type of cells may require more time to activate antioxidant defense.

Custodiol HTK induced significantly stronger iNOS expression as compared to Plegisol. The iNOS expression is considered as an apoptotic marker. As a result, it can be assumed that Custodiol appears as less destructive to cell self-defense mechanism than Plegisol, preventing the reactive impact of ROS. Besides, iNOS was successfully used in the past as myocardium ischemia markers by Jung et al. $\left[{ }^{31}\right]$ and F. Heinzel [22]. Also, Mayers et al. confirmed an increase in NOS activation during cardiac surgery with CPB $\left[{ }^{33}\right]$.

The assessment of protein HSP27 also revealed better protective properties of Custodiol HTK. The decrease of HSP27 concentration has been instantaneous and maintained throughout the study in both cultures incubated with Custodiol HTK. The absence of HSP27 after $0.5 \mathrm{~h}$ of incubation proves better protective abilities of Custodiol. Giannesi el al. also noticed a correlation between HSP synthesis and necrotic myocardial markers (Troponin-I, Myoglobin, LDH, CK, CK-MB) activation after heart operations $\left[{ }^{34}\right]$.

The level of lipid peroxidation was similar after incubation with both solutions. Our results corroborated sufficiently with Bical et al. and Zhang et al. examining various types of cardioplegia and different reperfusion techniques finding the similar intensity of peroxidation despite the protection method they used $[35,36]$. Protein damage reflected defined as carbonyl groups concentration was very irregular. The 
increased level of protein concentration was observed in $\mathrm{H} 9 \mathrm{C} 2$ cells at the longest time of exposition. On the contrary, In HCM cells carbonyl groups level has been nonspecific and not different from control cells, so it was challenging to select the solution of better protection from oxidation.

The in-vitro model of incubated cultured cardiomyocytes is quite innovative in the field of cardiac protection. Superior iNOS and HSP27 expressions, and MTT test, proved better potential protective properties of Custodiol HTK. Nevertheless, in the RCT by Demmy et al. showed no clinical advantage. Moreover, Custodiol HTK in the one-dose protocol generated a higher cTn-l level $6 \mathrm{~h}$ after operation than multi-dosed Plegisol $\left[{ }^{18}\right]$. Thus, the in-vitro superiority of Custodiol HTK has not been confirmed by this clinical study. Similarly, a systematic review by Edelman et al. showed no clear superiority of Custodiol over other cardioplegic solutions in preoperative myocardial protection $\left[{ }^{37}\right]$. In the author's opinion intraoperative myocardial protection is multifactorial when only one of those factors relates to a cardioplegia solution alone.

\section{Study Limitations}

The main limitation of our research is that in vitro studies results cannot be directly transferred into clinical practice without proper clinical assessment, optimally in a randomized fashion. However, they can deliver fundaments for myocardial protection improvement.

\section{Conclusions}

Our in-vitro study performed on human matured cardiomyocytes showed the superiority of Custodiol HTK due to better cellular preservation and better safety characteristics. Both Plegisol and Custodiol produced a similar expression of MnSOD and cytotoxicity test results. Considering proceeded examinations on cultured cardiomyocytes, Custodiol HTK appears to be more biocompatible and safer than Plegisol for maintaining cellular function.

\section{Abbreviations}

CPB - cardiopulmonary by-pass

H9C2 - rat cardiomyocytes

HCM - human cardiomyocytes

MnSOD - manganese superoxide dismutase

iNOS - inducible nitric oxide synthase

HSP27 - heat shock protein 27

OS - oxidative stress 
ROS - reactive oxygen species

MDA - malondialdehyde

MTT - 3-(4,5-dimethylthiazol-2-yl)-2,5-diphenyltetrazolium bromide (tetrazolium dye)

PBS - phosphate-buffered saline

TCA - trichloroacetic acid

TBA - thiobarbituric acid

TBARS - thiobarbituric acid reactive substances

DNPH - dinitrophenylhydrazine

DAKO - diaminobenzidine-H2O2

CABG - coronary artery by-pass grafting

cTn-I - cardiac troponin I

SOD - superoxide dismutase

CAT - catalase

\section{Declarations}

Ethics approval and consent to participate

This research was approved by the Bioethics Commission of Wroclaw Medical University

Consent for publication

Not applicable

\section{Availability of data and materials}

The datasets used and/or analyzed during the current study are available from the corresponding author on reasonable request.

\section{Competing interests}

The authors declare that they have no competing interests.

\section{Funding}


This work is a part of the author's PhD dissertation sponsored by the Polish Ministry of Science and Higher Education under Grant no N N403 573038.

\section{Authors' contributions}

MB translated and prepared the paper to submission

JK, KBK conducted biochemical tests

JS, JK analyzed and interpreted the data

MJ revised, counseled and commented on the paper

\section{Acknowledgments}

Authors would like to thank Professor Fluvio Ursini from the University of Padova for rat cardiomyoblasts we used in this study.

\section{References}

1. Baikoussis NG, Papakonstantinou NA, Verra C, et al. Mechanisms of oxidative stress and myocardial protection during open-heart surgery. Ann Card Anaesth. 2015; 18: 555-64.

2. Ansley DM, Wang B. Oxidative stress and myocardial injury in the diabetic heart. J Pathol. 2013; 229: 232-41.

3. Calafiore AM, Teodori G, Di Giammarco G, et al. Intermittent antegrade cardioplegia: warm blood vs cold crystalloid. A clinical study. J Cardiovasc Surg (Torino). 1994; 35: 179-84.

4. Vivacqua A, Robinson J, Abbas AE, et al. Single-dose cardioplegia protects myocardium as well as traditional repetitive dosing: A noninferiority randomized study. J Thorac Cardiovasc Surg. 2019. doi: 10.1016/j.jtcvs.2019.03.125

5. Bretschneider HJ, Hubner G, Knoll D, Lohr B, Nordbeck H, Spieckermann PG. Myocardial resistance and tolerance to ischemia: physiological and biochemical basis. J Cardiovasc Surg (Torino). 1975; 16: $241-60$.

6. Chambers DJ, Sakai A, Braimbridge MV, et al. Clinical validation of St. Thomas' Hospital cardioplegic solution No. 2 (Plegisol). Eur J Cardiothorac Surg.. 1989; 3: 346-52.

7. Rastan AJ, Eckenstein JI, Hentschel B, et al. Emergency coronary artery bypass graft surgery for acute coronary syndrome: beating heart versus conventional cardioplegic cardiac arrest strategies. Circ. 2006; 114: 1477-85.

8. Beurtheret S, Gariboldi V, Feier $\mathrm{H}$, et al. Short-term results of repeat valve replacement: a predictive factor analysis. J Heart Valve Dis. 2010; 19: 326-32.

9. Catinella FP, Cunningham JN, Jr., Spencer FC. Myocardial protection during prolonged aortic crossclamping. Comparison of blood and crystalloid cardioplegia. J Thorac Cardiovasc Surg. 1984; 88: 
411-23.

10. Engelman RM, Rousou JH, Lemeshow S, Dobbs WA. The metabolic consequences of blood and crystalloid cardioplegia. Circ. 1981; 64: II67-74.

11. Fremes SE, Christakis GT, Weisel RD, et al. A clinical trial of blood and crystalloid cardioplegia. J Thorac Cardiovasc Surg 1984; 88: 726-41.

12. Gundry SR, Kirsh MM. A comparison of retrograde cardioplegia versus antegrade cardioplegia in the presence of coronary artery obstruction. Ann Thorac Surg. 1984; 38: 124-7.

13. Guru V, Omura J, Alghamdi AA, Weisel R, Fremes SE. Is blood superior to crystalloid cardioplegia? A meta-analysis of randomized clinical trials. Circ. 2006; 114: I331-8.

14. Mezzetti A, Calafiore AM, Lapenna D, et al. Intermittent antegrade warm cardioplegia reduces oxidative stress and improves metabolism of the ischemic-reperfused human myocardium. J Thorac Cardiovasc Surg. 1995; 109: 787-95.

15. Ovrum E, Tangen G, Tollofsrud S, Oystese R, Ringdal MA, Istad R. Cold blood cardioplegia versus cold crystalloid cardioplegia: a prospective randomized study of 1440 patients undergoing coronary artery bypass grafting. J Thorac Cardiovasc Surg. 2004; 128: 860-5.

16. Rinne T, Pehkonen E, Kaukinen S, Tarkka M. Comparison of cardioprotection with crystalloid and blood cardioplegia in CABG patients. J Cardiothorac Vasc Anesth. 1993; 7: 679-83.

17. Kober IM, Obermayr RP, Brull T, Ehsani N, Schneider B, Spieckermann PG. Comparison of the solutions of Bretschneider, St. Thomas' Hospital and the National Institutes of Health for cardioplegic protection during moderate hypothermic arrest. Eur Surg Res. 1998; 30: 243-51.

18. Demmy TL, Molina JE, Ward HB, et al. Custodiol versus Plegisol: A phase 3 multicentre myocardial protection study. Int J Angiol. 2008; 17: 149-53.

19. Cannata A, Botta L, Colombo T, et al. Does the cardioplegic solution have an effect on early outcomes following heart transplantation? Eur J Cardiothorac Surg. 2012; 41: e48-52; discussion e-3.

20. Oldenburg O, Qin Q, Krieg T, et al. Bradykinin induces mitochondrial ROS generation via NO, cGMP, PKG, and mitoKATP channel opening and leads to cardioprotection. Am J Physiol Heart Circ Physiol. 2004; 286: H468-76.

21. Wei SS, Liao XX, Yang CT, et al. [Reactive oxygen species scavenger protects cardiac cells against injuries induced by chemical hypoxia]. Nan Fang Yi Ke Da Xue Xue Bao. 2009; 29: 1977-81.

22. Dong XB, Yang CT, Zheng DD, et al. Inhibition of ROS-activated ERK1/2 pathway contributes to the protection of H2S against chemical hypoxia-induced injury in H9c2 cells. Mol Cell Biochem. 2012; 362: 149-57.

23. Camilleri L, Moins N, Papon J, et al. Validity of a model of cultured myocardial cells for assessment of cardioplegia. Cell Biol Toxicol. 1997; 13: 435-44.

24. Gomez LA, Alekseev AE, Aleksandrova LA, Brady PA, Terzic A. Use of the MTT assay in adult ventricular cardiomyocytes to assess viability: effects of adenosine and potassium on cellular survival. J Mol Cell Cardiol. 1997; 29: 1255-66. 
25. Drescher C, Diestel A, Wollersheim S, Berger F, Schmitt KR. How does hypothermia protect cardiomyocytes during cardioplegic ischemia? Eur J Cardiothorac Surg. 2011; 40: 352-9.

26. Nowicki R, Saczko J, Kulbacka J, et al. The estimation of oxidative stress markers and apoptosis in right atrium auricles cardiomyocytes of patients undergoing surgical heart revascularisation with the use of warm blood cardioplegia. Folia Histochem Cytobiol. 2010; 48: 202-7.

27. Shlafer M, Kane PF, Kirsh MM. Superoxide dismutase plus catalase enhances the efficacy of hypothermic cardioplegia to protect the globally ischemic, reperfused heart. J Thorac Cardiovasc Surg. 1982; 83: 830-9.

28. Lee S, Kim K, Kim YH, et al. Preventive role of propofol in hypoxia/reoxygenation-induced apoptotic H9c2 rat cardiac myoblast cell death. Mol Med Rep. 2011; 4: 351-6.

29. Yu X, Ge L, Niu L, Lian X, Ma H, Pang L. The Dual Role of Inducible Nitric Oxide Synthase in Myocardial Ischemia/Reperfusion Injury: Friend or Foe? Oxid Cell Med Longev 2018; 2018: 8364848

30. Buelna-Chontal M, Garcia-Nino WR, Silva-Palacios A, Enriquez-Cortina C, Zazueta C. Implications of Oxidative and Nitrosative Post-Translational Modifications in Therapeutic Strategies against Reperfusion Damage. Antioxidants 2021; 10(5), 749

31. Jung F, Palmer LA, Zhou N and Johns RA. Hypoxic regulation of inducible nitric oxide synthase via hypoxia inducible factor-1 in cardiac myocytes. Circ Res. 2000; 86: 319-25.

32. Heinzel FR, Gres P, Boengler K, et al. Inducible nitric oxide synthase expression and cardiomyocyte dysfunction during sustained moderate ischemia in pigs. Circ Res. 2008; 103: 1120-7.

33. Mayers I, Hurst T, Puttagunta L, et al. Cardiac surgery increases the activity of matrix metalloproteinases and nitric oxide synthase in human hearts. J Thorac Cardiovasc Surg. 2001; 122 : $746-52$.

34. Giannessi D, Caselli C, Vitale RL, et al. A possible cardioprotective effect of heat shock proteins during cardiac surgery in pediatric patients. Pharmacol Res. 2003; 48: 519-29.

35. Bical O, Gerhardt MF, Paumier D, et al. Comparison of different types of cardioplegia and reperfusion on myocardial metabolism and free radical activity. Circ. 1991; 84: III375-9.

36. Zhang Q, Meng BY, Peng L, Wang T, Ma C, Tao J. [Myocardial protection of cold autoblood cardioplegia in infants with congenital heart disease]. Zhongguo Dang Dai Er Ke Za Zhi. 2009; 11: 638-40.

37. Edelman JJ, Seco M, Dunne B, Matzelle SJ et al. Custodiol for myocardial protection: a systematic review. Ann Cardiothorac Sure 2013; 2(6):717-728

\section{Tables}

Table 1. The composition of Custodiol HTK and Plegisol (after buffering with NaHCO\&). 


\begin{tabular}{|c|c|c|}
\hline \multirow{2}{*}{$\begin{array}{l}\text { composition } \\
\text { [mmol/L] }\end{array}$} & \multicolumn{2}{|l|}{ Cardioplegia } \\
\hline & Custodiol HTK & Plegisol (STH-2) \\
\hline $\mathrm{K} \nabla$ & 9.0 & 16.0 \\
\hline $\mathrm{Na} \rrbracket$ & 15.0 & 120.0 \\
\hline Mg怄 & 4.0 & 16.0 \\
\hline $\mathrm{CaD}$ & - & 1.2 \\
\hline $\mathrm{NaHCO} \otimes[\mathrm{mEq} / \mathrm{L}]$ & - & 10.0 \\
\hline $\mathrm{pH}$ & $7.1-7.2$ & 7.8 \\
\hline osmolality [mosM/KgH囚O] & $295-325$ & 280 \\
\hline \multirow[t]{4}{*}{ adds } & Histidine & - \\
\hline & Tryptophan & \\
\hline & Ketoglutarane & \\
\hline & Mannitol & \\
\hline
\end{tabular}

Table 2. The immunocytochemical evaluation of MnSOD stained reaction in:

A) H9C2 cells

\begin{tabular}{|c|c|c|c|}
\hline incubation time [h] & Custodiol HTK & Plegisol & control cells \\
\hline \multirow[t]{2}{*}{0.5} & $67 \% *$ & $69 \% *$ & $10 \%$ \\
\hline & $+/++$ & + & + \\
\hline \multirow[t]{2}{*}{1} & $70 \% *$ & $95 \% *$ & \\
\hline & $+/++$ & ++ & \\
\hline \multirow[t]{2}{*}{2} & $96 \% *$ & $95 \% *$ & \\
\hline & ++ & ++ & \\
\hline \multirow[t]{2}{*}{4} & $95 \% *$ & $98 \% *$ & \\
\hline & ++ & ++ & \\
\hline
\end{tabular}




\begin{tabular}{|c|c|c|c|}
\hline incubation time [h] & Custodiol HTK & Plegisol & control cells \\
\hline \multirow[t]{2}{*}{0.5} & $80 \%{ }^{*}$ & $99 \% *$ & $10 \%$ \\
\hline & ++ & $++/+++$ & + \\
\hline \multirow[t]{2}{*}{1} & $85 \%{ }^{*}$ & $98 \%$ & \\
\hline & $++/+++$ & $+/++$ & \\
\hline \multirow[t]{2}{*}{2} & $97 \%{ }^{*}$ & $77 \%{ }^{*}$ & \\
\hline & $++/+++$ & + & \\
\hline \multirow[t]{2}{*}{4} & $98 \%{ }^{*}$ & $98 \%{ }^{*}$ & \\
\hline & $+/++$ & $++/+++$ & \\
\hline
\end{tabular}

* for $p \leq 0.001$

Table 3. The immunocytochemical evaluation iNOS expression in:

A. H9C2 cells

\begin{tabular}{llll} 
incubation time $[\mathrm{h}]$ & Custodiol HTK & Plegisol & control cells \\
\hline 0.5 & $<5 \%$ & $<5 \%$ & 0 \\
& $-/+$ & $-/+$ & \\
\cline { 1 - 3 } 1 & $<5 \%$ & $<5 \%$ & \\
& $-/+$ & $-/+$ & \\
\hline 2 & $5-7 \%$ & $<5 \%$ & \\
& + & $-/+$ & \\
4 & $20 \%^{*}$ & $25 \%^{*}$ \\
& + & +
\end{tabular}

* for $p \leq 0.005$

B. HCM cells 


\begin{tabular}{|c|c|c|c|}
\hline incubation time [h] & Custodiol HTK & Plegisol & control cells \\
\hline \multirow[t]{2}{*}{0.5} & $70 \%{ }^{*}$ & & 0 \\
\hline & $+/++$ & + & \\
\hline \multirow[t]{2}{*}{1} & $85 \%{ }^{*}$ & $<5 \%$ & \\
\hline & ++ & + & \\
\hline \multirow[t]{2}{*}{2} & $95 \%, *$ & $85 \%{ }^{*}$ & \\
\hline & $++/+++$ & ++ & \\
\hline \multirow[t]{2}{*}{4} & $95 \%, *$ & $25 \%$ & \\
\hline & $++/+++$ & + & \\
\hline
\end{tabular}

* for $p \leq 0.05$

Table 4. The immunocytochemical evaluation of HSP27 expression in:

A) $\mathrm{H} 9 \mathrm{C} 2$ cells

\begin{tabular}{|c|c|c|c|}
\hline incubation time $[\mathrm{h}]$ & Custodiol HTK & Plegisol & control cells \\
\hline \multirow[t]{2}{*}{0.5} & $<5 \%{ }^{*}$ & $<5 \%^{*}$ & $45 \%$ \\
\hline & $-1+$ & + & ++ \\
\hline \multirow[t]{2}{*}{1} & $18 \%{ }^{*}$ & $20 \%^{*}$ & \\
\hline & + & + & \\
\hline \multirow[t]{2}{*}{2} & $20-12 \%$ & $40 \%$ & \\
\hline & + & + & \\
\hline \multirow[t]{2}{*}{4} & $25 \%^{*}$ & $70 \%{ }^{*}$ & \\
\hline & + & $+/++$ & \\
\hline
\end{tabular}

* for $p \leq 0.001$

B) HCM cells 


\begin{tabular}{|c|c|c|c|}
\hline incubation time [h] & Custodiol HTK & Plegisol & control cells \\
\hline \multirow[t]{2}{*}{0.5} & no reaction & $<5 \%$ & $45 \%$ \\
\hline & & + & ++ \\
\hline \multirow[t]{2}{*}{1} & no reaction & $30 \%$ & \\
\hline & & $+/++$ & \\
\hline \multirow[t]{2}{*}{2} & no reaction & $50 \%^{*}$ & \\
\hline & & $+/++$ & \\
\hline \multirow[t]{2}{*}{4} & $<5 \%^{*}$ & no reaction & \\
\hline & $+/++$ & & \\
\hline
\end{tabular}

* for $p \leq 0.05$

Figures

A)

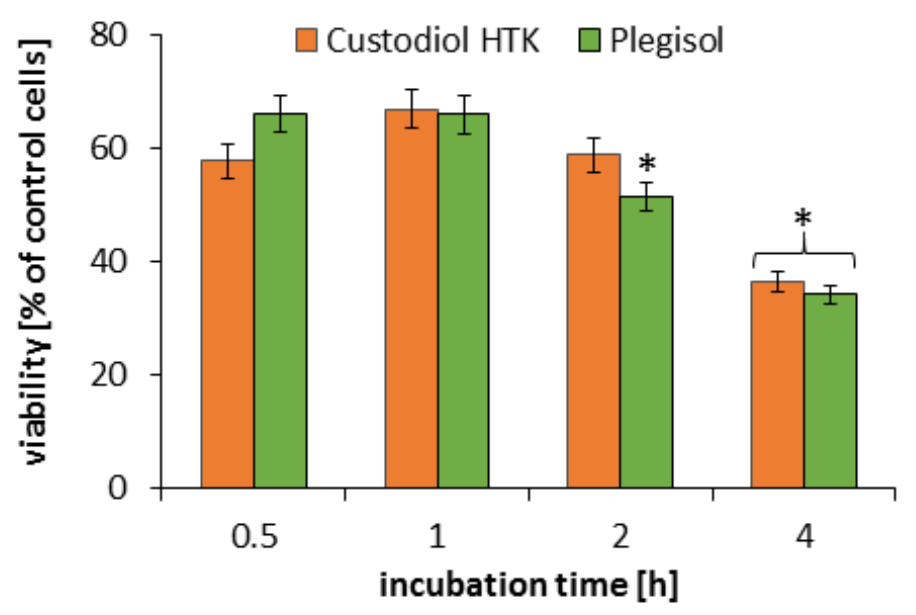

B)

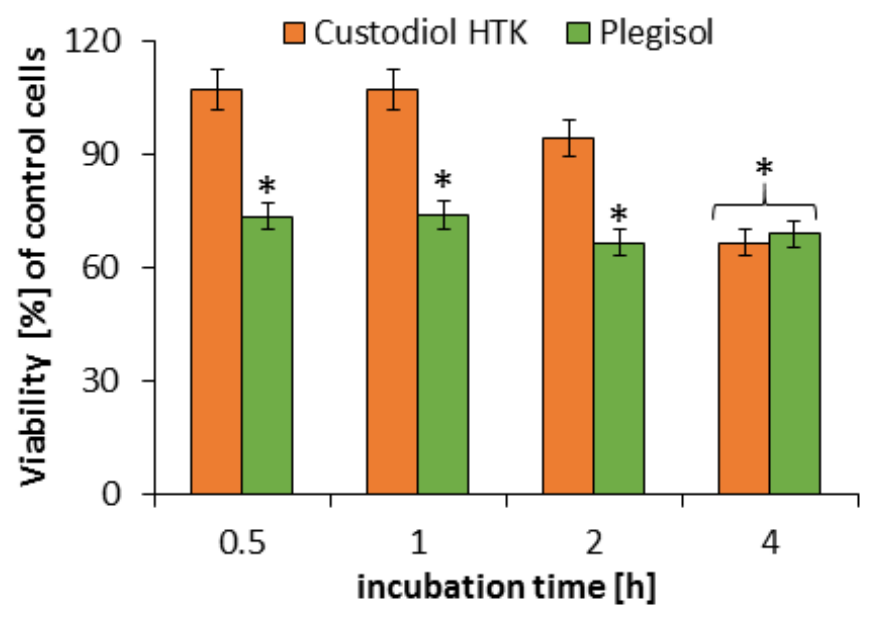

Figure 1

The viability assay after incubation with cardioplegia in A) rat $\mathrm{H} 9 \mathrm{C} 2$ cells and $\mathrm{B}$ ) human $\mathrm{HCM}$ cells. The results are averaged. The standard deviation is marked with the error bar. *statistically significant for $\mathrm{p}<0.05$. 
A)

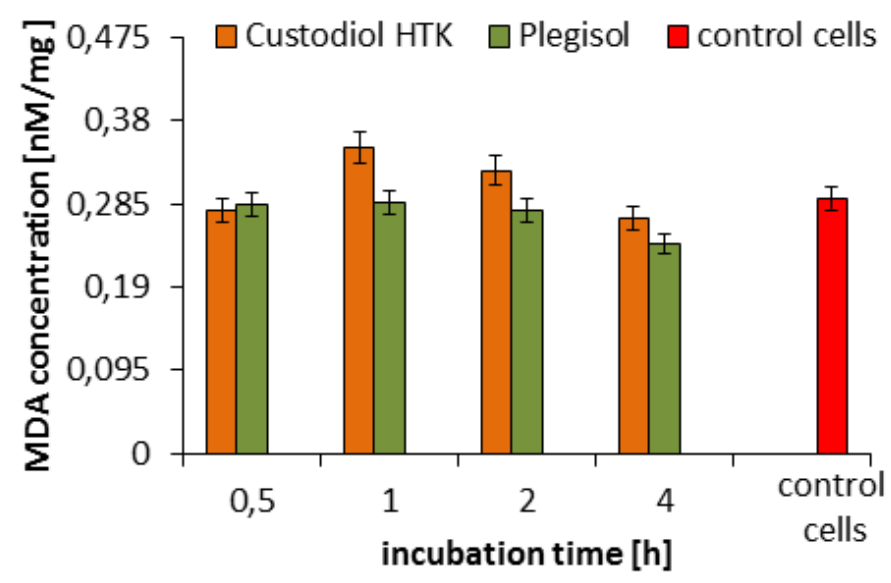

B)

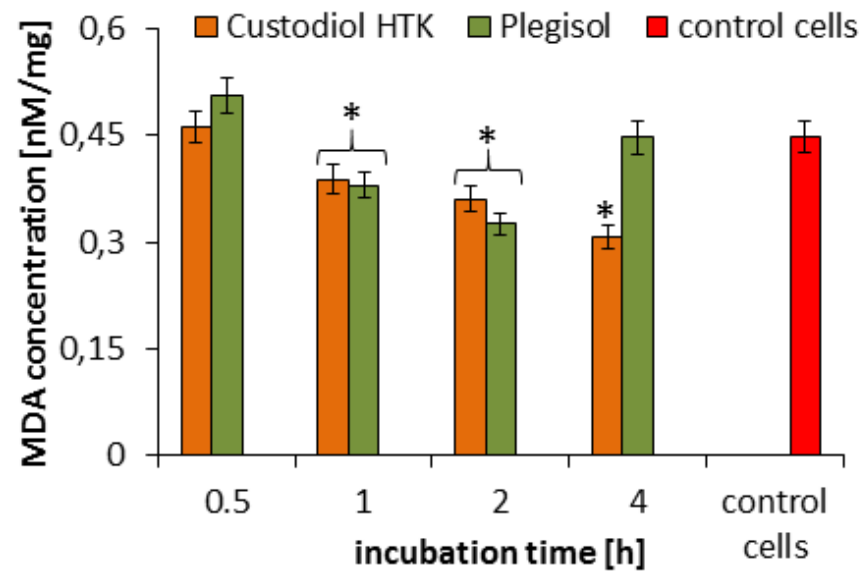

Figure 2

The evaluation of lipid peroxidation by malondialdehyde (MDA) concentration level in A) rat $\mathrm{H} 9 \mathrm{C} 2$ cells and $\mathrm{B}$ ) human HCM cells after incubation with cardioplegia. The results are averaged. The standard deviation is marked with the error bar. *statistically significant for $p<0.05$.

A)

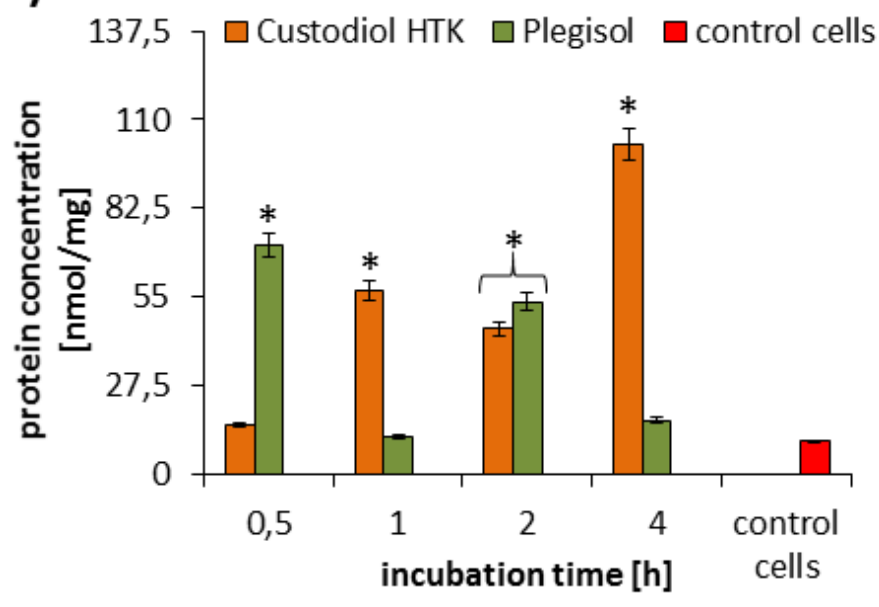

B)

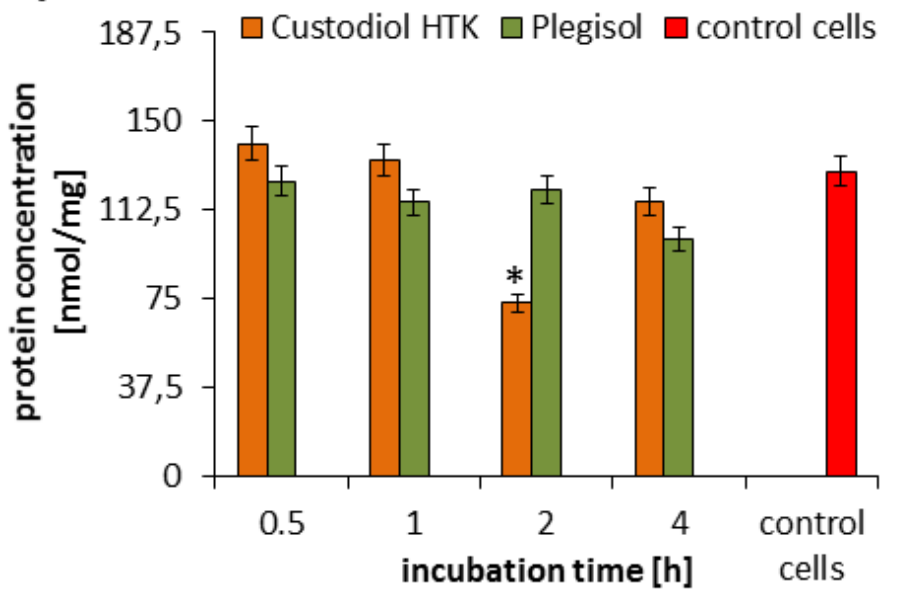

\section{Figure 3}

The evaluation of protein damage by carbonyl group concentration level in A) rat $\mathrm{H} 9 \mathrm{C} 2$ cells and $\mathrm{B}$ ) human HCM cells after incubation with cardioplegia. The results are averaged. The standard deviation is marked with the error bar. *statistically significant for $p<0.05$. 

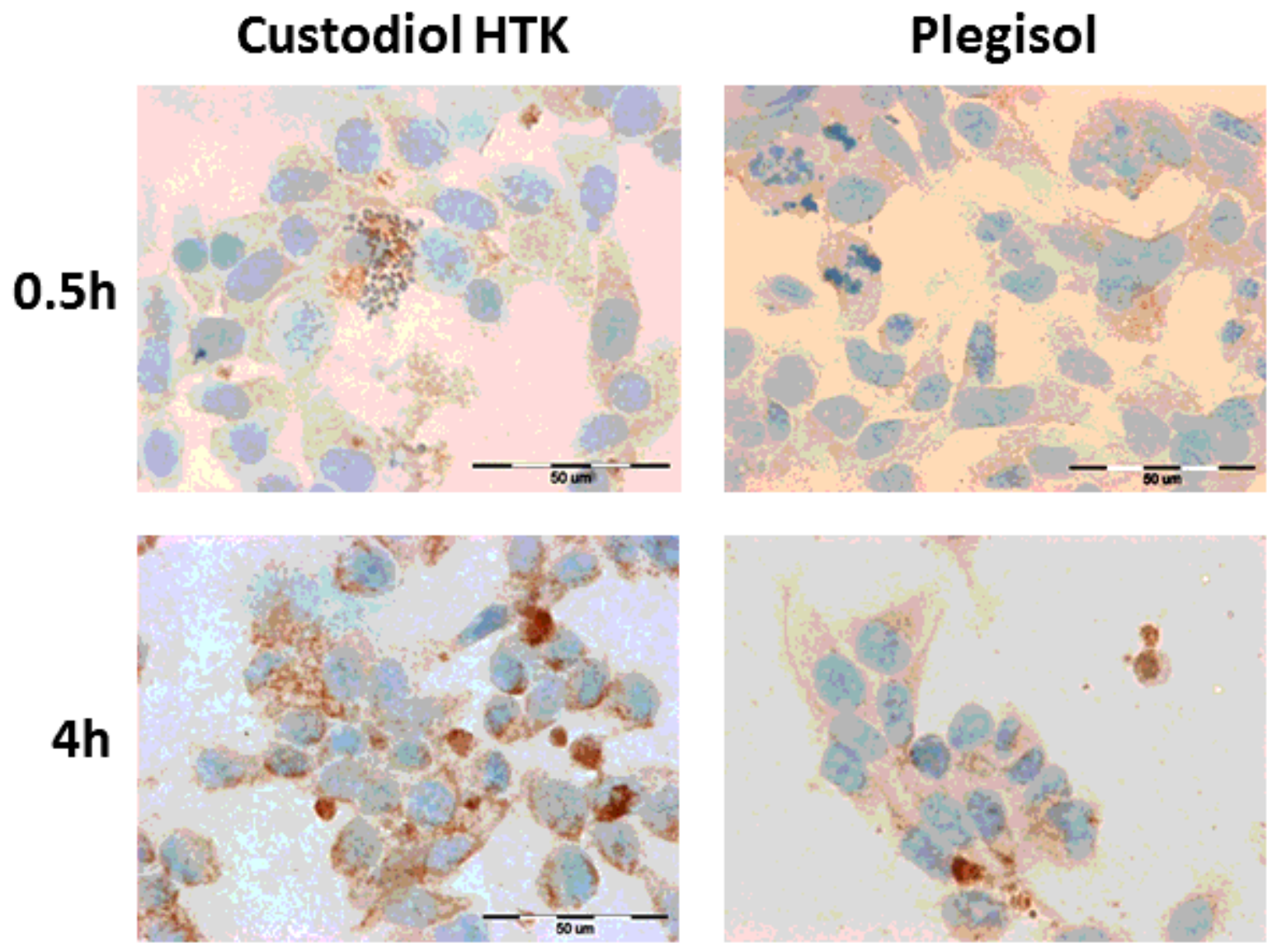

Plegisol

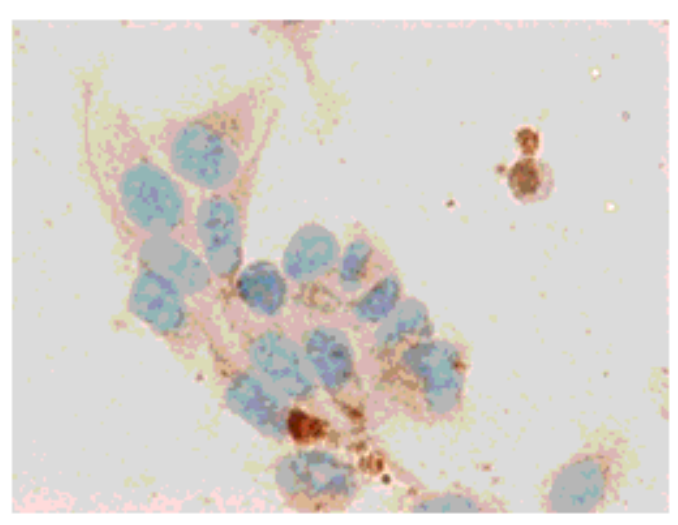

\section{Figure 4}

The evaluation of MnSOD immunocytochemical reaction in rat $\mathrm{H} 9 \mathrm{C} 2$ cells after $0.5 \mathrm{~h}$ and $4 \mathrm{~h}$ of incubation with Custodiol HTK or Plegisol. 


\section{Custodiol HTK}
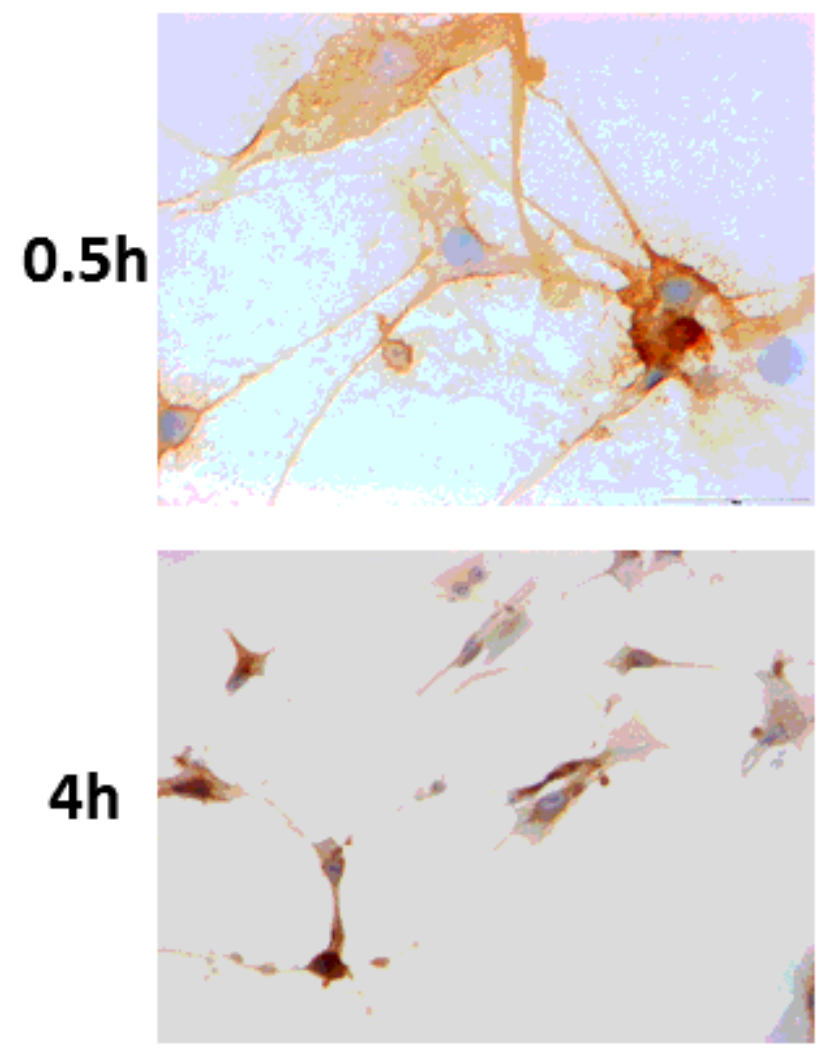

Plegisol
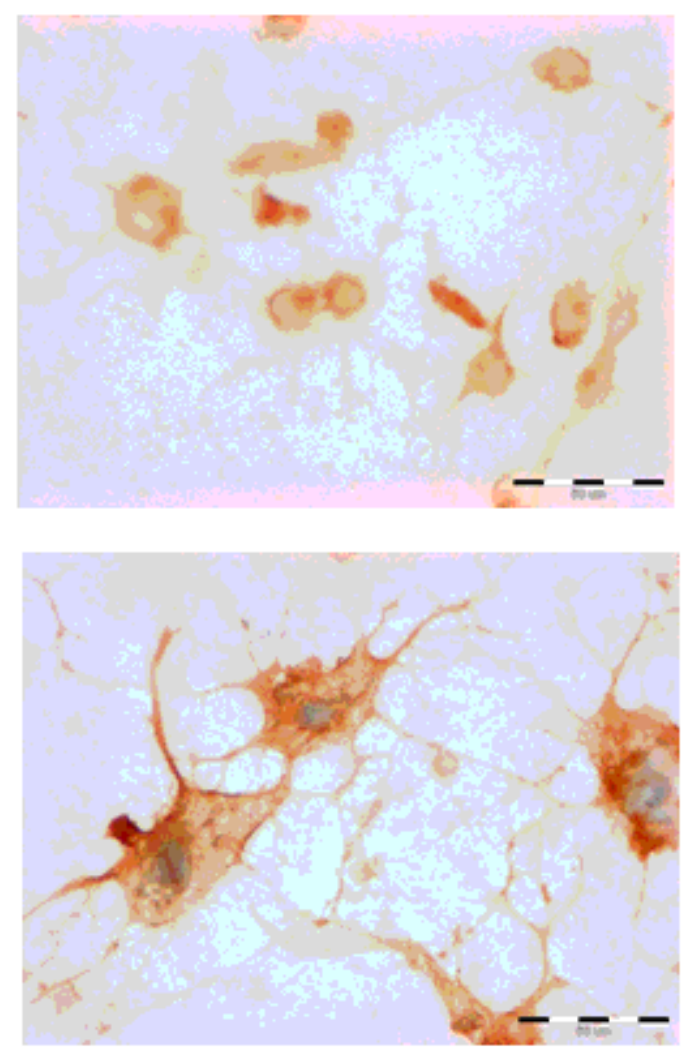

\section{Figure 5}

The evaluation of MnSOD immunocytochemical reaction in human HCM cells after $0.5 \mathrm{~h}$ and $4 \mathrm{~h}$ of incubation with Custodiol HTK or Plegisol.
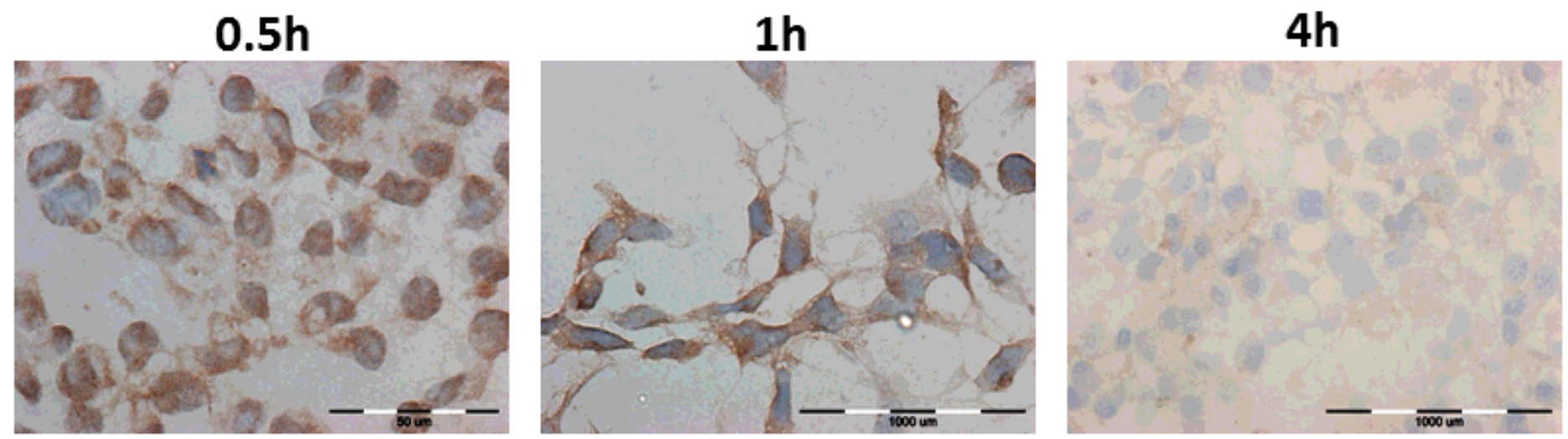

Figure 6

The evaluation of iNOS immunocytochemical reaction in rat $\mathrm{H} 9 \mathrm{C} 2$ cells after $0.5 \mathrm{~h}, 1 \mathrm{~h}$ and $4 \mathrm{~h}$ of incubation with Plegisol. 


\section{Custodiol HTK}
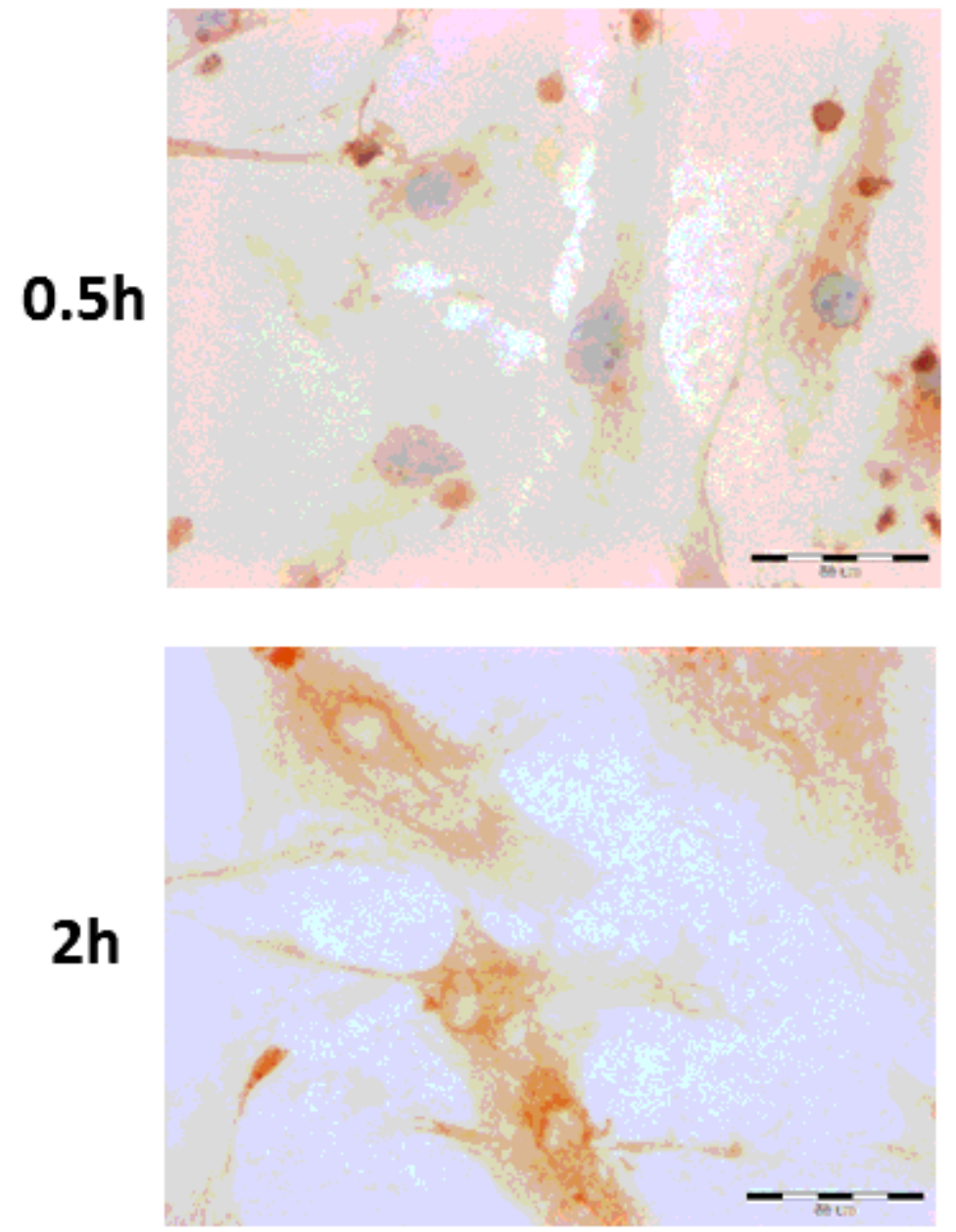

Plegisol
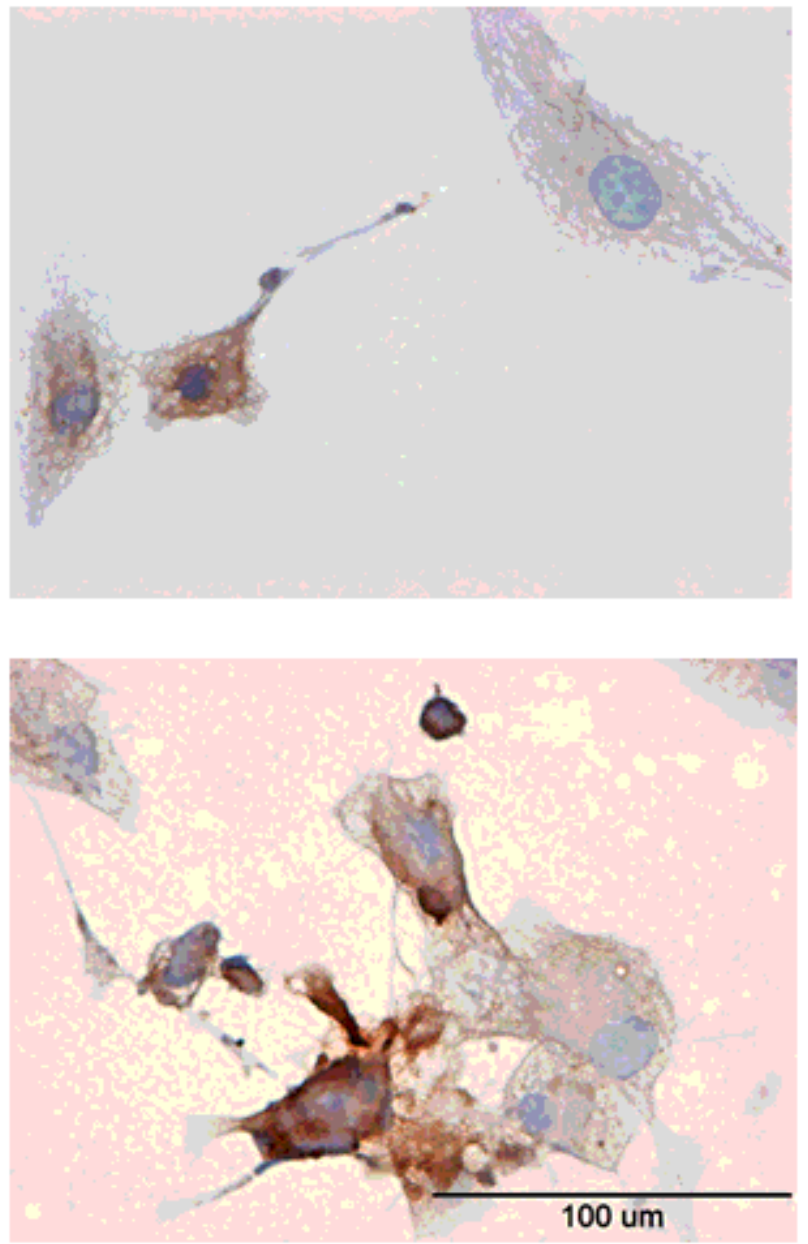

Figure 7

The evaluation of iNOS immunocytochemical reaction in human HCM cells after $0.5 \mathrm{~h}$ and $2 \mathrm{~h}$ of incubation with Custodiol HTK or Plegisol. 
Custodiol HTK

$0.5 \mathrm{~h}$
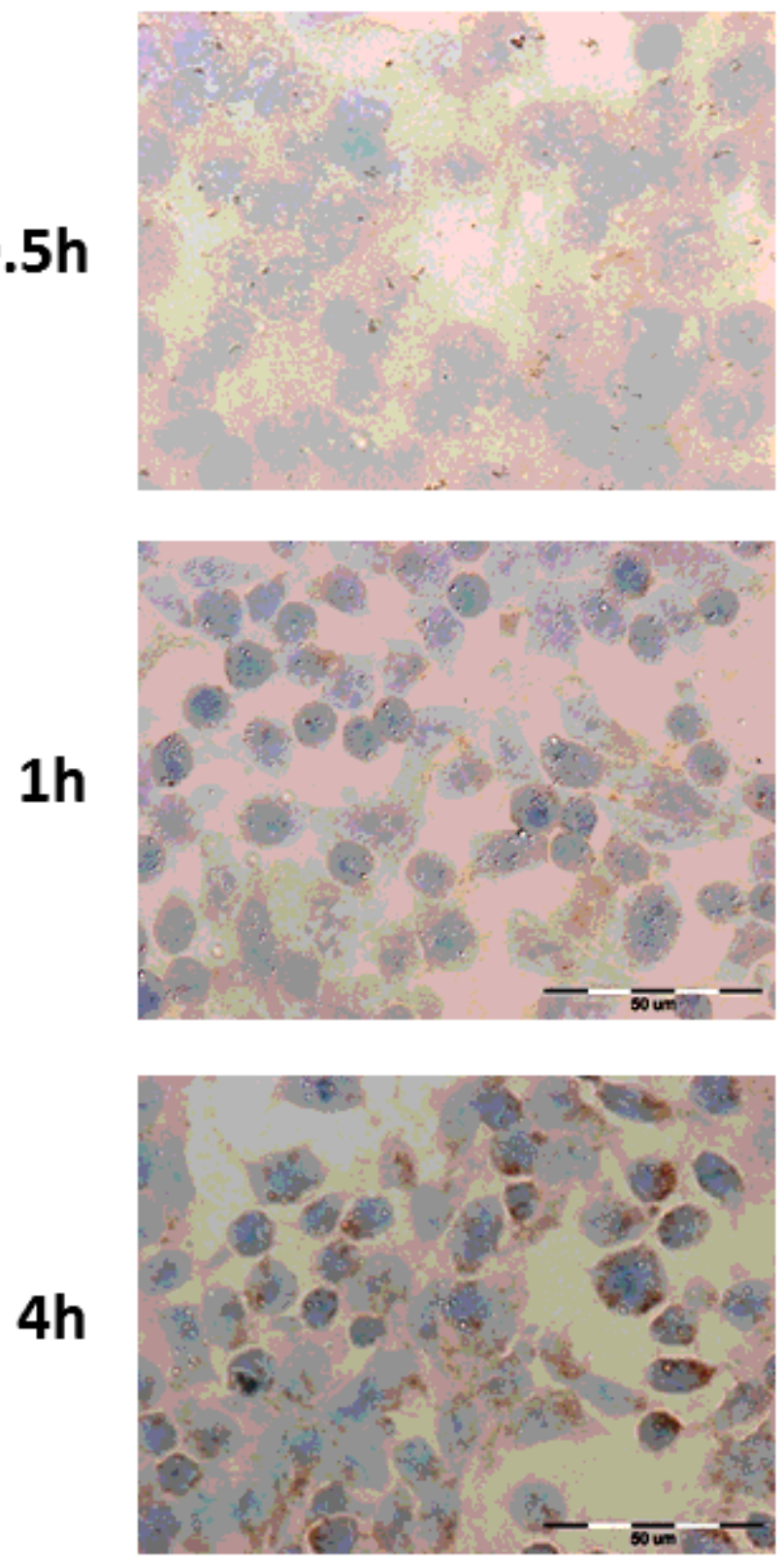

Plegisol
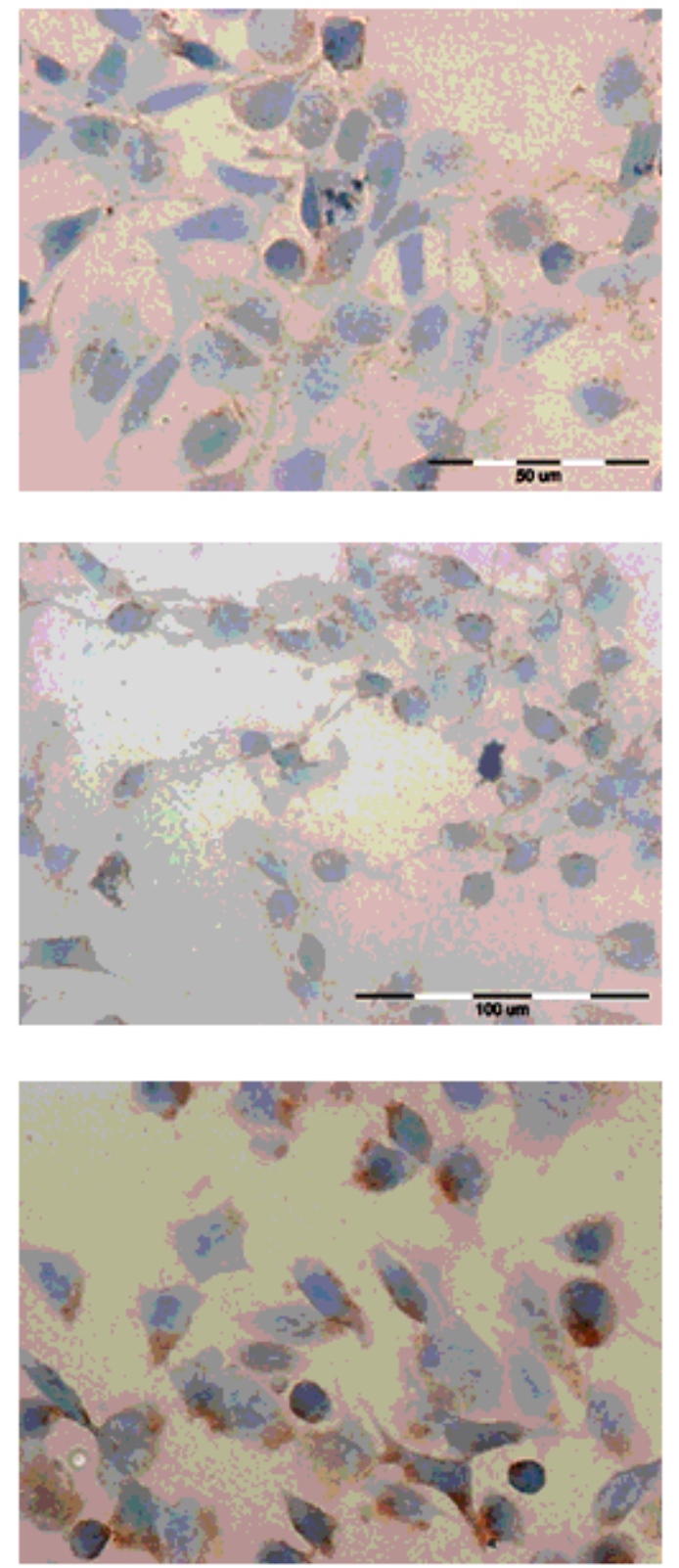

\section{Figure 8}

The evaluation of HSP27 immunocytochemical reaction in rat $\mathrm{H} 9 \mathrm{C} 2$ cells after $0.5 \mathrm{~h}, 1 \mathrm{~h}$ and $4 \mathrm{~h}$ of incubation with Custodiol HTK or Plegisol. 
$0.5 h$

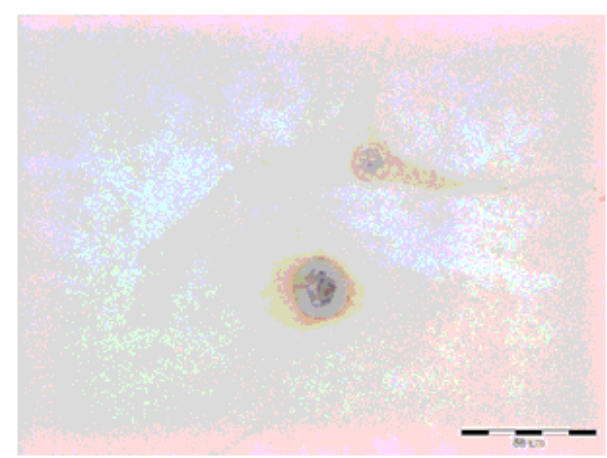

$1 \mathrm{~h}$

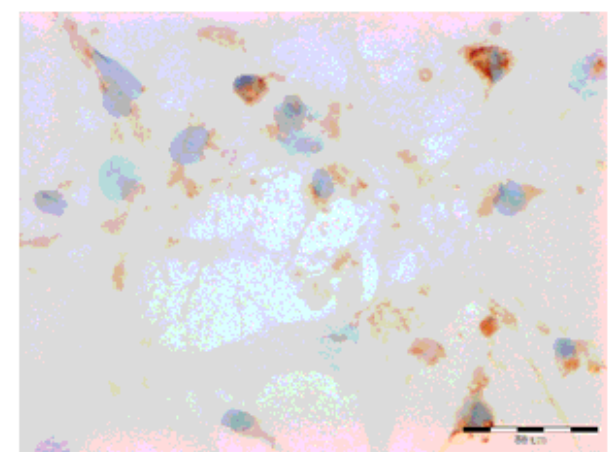

$2 \mathrm{~h}$

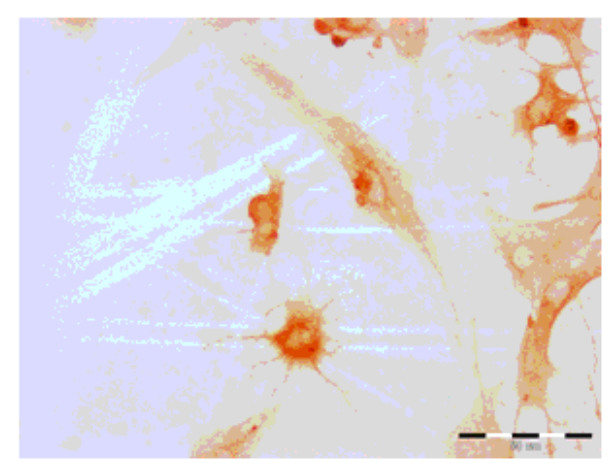

Figure 9

The evaluation of HSP27 immunocytochemical reaction in human HCM cells after $0.5 \mathrm{~h}, 1 \mathrm{~h}$ and $2 \mathrm{~h}$ of incubation with Plegisol. 